\title{
MOLINISM, QUESTION-BEGGING, AND FOREKNOWLEDGE OF INDETERMINATES
}

\author{
JOHN D. LAING* \\ Southwestern Baptist Theological Seminary
}

\begin{abstract}
John Martin Fischer's charge that Molinism does not offer a unique answer to the dilemma of divine foreknowledge and human freedom can be seen as a criticism of middle knowledge for begging the question of $\mathrm{FF}$ (foreknowledge and freedom)-compatibilism. In this paper, I seek to answer this criticism in two ways. First, I demonstrate that most of the chief arguments against middle knowledge are guilty of begging the question of FF-incompatibilism and conclude that the simple charge of begging the question cannot be as problematic as some suggest. Determinists and open theists incorporate FF-incompatibilist notions into their respective versions of the grounding objection, their conceptions of risk and libertarian freedom, and their requirements for divine foreknowledge. Thus, while I admit that Molinism does rely upon Ockhamist and Augustinian principles in its approach to the dilemma and is guilty of presupposing FF-compatibilism, I deny that this undermines its strength as a model of providence. Second, I argue that, although all models are guilty of question-begging moves, they are not all on par with one another. Molinism offers a more orthodox and robust approach to providence than open theism and process theology, and it handles empirical data (e.g., from science) better than all of its competitors.
\end{abstract}

KEY WORDS: Molinism, providence, foreknowledge, free will, open theism

\section{Introduction}

John Martin Fischer, building on comments by William Hasker, has persuasively argued that Molinism does not provide its own answer to the dilemma of foreknowledge and freedom and instead assumes one, though he does not identify which one specifically (Fischer 2008, 2009, 2012; cf. Hasker 1989: 18). He writes, 'Molinism does not stand on a par with the views of Boethius, Aquinas and Ockham, which are indeed attempts to answer the

* JOHN D. LAING (PhD 2000, Southern Baptist Theological Seminary) is Professor of Systematic Theology and Philosophy at Southwestern Baptist Theological Seminary, Havard School for Theological Studies. Email: jlaing@swbts.edu. Alternatively, please use chaplainlaing@gmail.com. 
incompatibilist's worries. At best, the theory of middle knowledge explains how God knows about future contingents, given that he can know about them at all (something it does not seek to address)' (Fischer 2012: 216). Fischer's argument proceeds by comparing two propositions:

(1) At some future time agent $A$ will be free to do other than he actually does $(X)$

and

(2) If agent $A$ were in (possible) circumstance $C l, A$ would be free to do other than he actually does $(X)$;

and arguing that, just as it would be question-begging to claim that God knows truths such as (1) in advance, so also would it be to claim that God knows propositions such as (2) in advance.

To claim that God has knowledge of (1) prior to the future time just is to ignore the force of the fatalist/incompatibilist challenge! Appealing to possible worlds semantics, Fischer argues similarly that to claim that God has knowledge of (2) just is to ignore the fatalist/incompatibilist challenge. If $\mathrm{Cl}$ is possible, then there is a possible world where $\mathrm{Cl}$ obtains, and God knows this via his natural knowledge. Fischer writes,

Since (according to the Molinist) He also knows (via His middle knowledge) the conditional, 'If agent $A$ were in (possible) circumstance, $C l, A$ would be free to do other than he actually does $(X)$ ', it follows that God knows that there is a possible world in which $A$ is free to do other than he actually does... Molinism here simply posits that it is possible that God knows in advance that a human agent is free to do otherwise. But the [FF-] incompatibilist's argument putatively establishes that God's foreknowledge is incompatible with human freedom to do otherwise (Fischer 2012: 214).

Fischer distinguishes two interpretations of the 'how question' (regarding God's knowledge of the future): a 'nuts-and-bolts' answer, which explains how God can come to know the future free actions of creatures who possess libertarian freedom, and a 'philosophical' answer, which explains how God can know the future free actions of creatures who possess libertarian freedom without making their actions necessary. He complains that many proponents of Molinism mistakenly assume that the two are the same or that in providing the former, Molinism also gives an answer to the latter. However, Fischer notes, Molinism only provides a 'nuts-and-bolts' answer without providing the more important philosophical answer. Thus, I take Fischer's point to be that Molinism has libertarian freedom built into the counterfactuals God uses in his creation decisions (and thereby knowing the future), 
such that Molinism begs the question of FF-compatibilism (compatibilism between divine foreknowledge and creaturely freedom, not to be confused with compatibilism simpliciter, i.e., between determinism and free will). That is, Molinism presupposes FF-incompatibilism is false and builds the reconciliation of foreknowledge and freedom into its structure without seriously considering the coherence of its suggestion. Put differently, Molinism assumes that one of the other answers to the philosophical 'how-question' to the FF-incompatibilist challenge (i.e., Augustinian, Boethian, Ockhamist) is correct and covertly works it into its structure.

How are we to respond to Fischer's argument? On the one hand, some Molinists may feel that no formal response is necessary since Fischer is merely making an observation; he does not cast his essay in terms of a critique of Molinism or its contemporary proponents, and even specifically notes that Thomas Flint makes no grandiose claims for Molinism's ability to answer the dilemma. Fischer sees his work as more of a corrective for the philosophical community in general 'to identify its [Molinism's] niche more precisely in dialectical space' (Fischer 2012: 217). He even concedes that Molinism may prove to be a powerful model of divine providence, if counterfactuals of freedom are indeed true. On the other hand, some may see a need to respond, as there are a couple of ways in which Fischer's point could still be viewed as critical of Molinism. First, the charge of begging the question is typically seen as a defect in logic or argument, and Fischer basically charges Molinism with begging the question of FF-compatibilism (or at least presupposes an undefended model). Second, near the end of his article Fischer seems to endorse Robert Adams's arguments against counterfactuals of creaturely freedom and thus raises doubts about the viability of middle knowledge, even as a model of providence. Thus, a complete response to Fischer's article will need not only to engage his claim that Molinism offers no philosophical answer to the FF-incompatibilist challenge, but also to address his concerns with Molinism's viability and veracity.

So, what should be made of Fischer's basic claim that Molinism assumes an answer to the FF-incompatibilist challenge, or that it has FFcompatibilism built into the system? More importantly, if Fischer is correct, does this constitute a flaw in Molinism such that it should be rejected or such that it adds nothing to the discussion of foreknowledge and freedom? And if Fischer is correct, what has Molinism assumed/presupposed?

\section{Begging the Question}

Perhaps Molinism has presupposed an answer to the philosophical question and begged the question, but that may not be so bad after all. It seems that virtually all participants in the discussion of foreknowledge and free will may be accused of question-begging moves. Let me offer some examples 
from both open theists and determinists, beginning with one of the strongest critics of middle knowledge, William Hasker.

Hasker, Molinism, and Risk. Hasker has argued that Molinism's picture of divine providence is akin to determinism. According to Hasker, God must take risks if the created order is to avoid some kind of determinism, and risk is defined in terms of a lack of knowledge on the part of the risk-taker: 'God takes risks if he makes decisions that depend for their outcomes on the responses of free creatures in which the decisions themselves are not informed by knowledge of their outcomes' (Hasker 2004: 125). Thus, Hasker argues, if God's decisions are guided by comprehensive knowledge of how events will turn out, including how creatures will respond to him, then he takes no risks. The element of risk is lost because of the combination of God's work in creating and God's knowledge of the counterfactuals of freedom. Hasker notes,

But Molinism shows how God can entirely avoid taking any risks; prior to his decision to create anything or to place any free agent in a situation where she would make a choice, God knows exactly what choice would be made and so he knows, prior to any decisions of his own concerning his actions in creation and providence, exactly what the consequences would be of his making and carrying out any such decision (Hasker 1992: 95).

While he admits that this is not quite the same as Calvinism, it is still problematic because Molinism places the creature's decision in the past, before creation rather than at the time of decision, and therefore removes all risk. He writes, 'God becomes the archmanipulator, knowing in every case exactly 'which button to push > in order to elicit precisely the desired result from his creatures' (Hasker 1994: 145-146). The relationship of God to humanity, Hasker suggests, is akin to that of a cybergeneticist to a robot he created. While he again admits there are some differences between Calvinism and Molinism, he concludes: 'But the robot-master still knows all about that part of the program and is able just as before [Calvinism] to fine-tune the situations that the robot encounters so as to achieve just the desired result. Whether the change from Calvinism to Molinism makes the situation appreciably better in this regard is left for the reader to decide' (Hasker 1989: 146).

Molinist Responses. Molinists have responded to this argument in several ways. The strongest has been to call into question Hasker's definition of risk. [The conception of risk utilized by Hasker is dependent upon the knowledge of God, not on the actions of the creature. Yet it may be argued that a different rendering of risk fits quite nicely with middle knowledge. 
Risk can be located in the freedom of the creatures and the choice of God to create. While it is true that there is not risk in the sense that God does not know what is going to happen, there is risk in the sense that creatures imbued with freedom may choose to do something other than what God wishes. Some actions may go against the will of God as specific acts, yet may still fit into his overarching plan. In this sense, God is limited in what he can do due to the counterfactuals of freedom. The concept of world feasibility is in play here. Basinger claims that God might be 'quite lucky' in that he may be able to have his will accomplished through the free actions of individuals, but then again, he may not (Basinger 1993: 61). It is here that risk is located. Since God cannot force all events to abide by his will, there is risk in his very choice/act of creating free creatures. If all risk were eliminated, then all outcomes would necessarily be those which God most prefers, but this is not the case with middle knowledge. Basinger notes that Hasker's contention that middle knowledge eliminates risk is based on a confusion. He writes, 'Specifically, Hasker is confusing two distinct understandings of what it means for God to be a risk-taker: God is a risk-taker in the sense that he commits himself to a course of action without full knowledge of the outcome; and God is a risk-taker in the sense that he adopts certain overall strategies-for example, the granting of siginificant freedom-which create the potential for the occurrence of events that he wishes would not occur' (Basinger 1996: 48; cf. Basinger 1991: 135). Basinger goes on to correctly observe that it is the second type of risk which middle knowledge affords God, and it is this type of risk which the proponent of what Basinger calls basic freewill theism (BFWT) needs in order to remain consistent: 'Consequently, any alleged incompatibility between MK [middle knowledge] and BFWT that is based on the risk inherent in BFWT can be disregarded' (Basinger 1996: 48). Thus, it may be concluded that the Molinist is under no obligation to accept Hasker's definition of risk. In fact, two of the major proponents of Hasker's approach to divine providence and co-authors of The Openness of God have also rejected his understanding of risk. The first is Basinger; the second is John Sanders (1998: 171-172).]

Other definitions that comport well with Molinism can and have been given, so that Molinism may properly be seen as a risk taking model of divine providence. More importantly, Hasker seems to have begged the question of the incompatibility of foreknowledge and freedom. His definition of risk, coupled with his insistence that God take risks if creatures are to be free, amounts to an a priori dismissal of divine foreknowledge (assuming humans are free). If one grants Hasker's presuppositions of the necessity of divine risk for creaturely freedom and the elimination of risk by divine foreknowledge, then all attempts to reconcile the two are defeated from the start. Of course, Molinists do not so grant the presuppositions. 
Counterfactuals and Grounding. Even the grounding objection is subject to the criticism that it begs the question of indeterminism. Recall that the grounding objection is the charge that counterfactuals of freedom cannot be true because there is nothing (or no one) to which one can point that guarantees their truth. Robert Adams writes, 'One reason for doubting the truth of counterfactuals of freedom is that it is hard to see what would ground it' (Adams 1991: 345). Hasker agrees, asking, 'What, if anything, is the ground of the truth of the counterfactuals of freedom?' (Hasker 1989: 29) Adams and Hasker go on to argue that counterfactuals cannot be grounded in God, the individual to whom they refer, or causal activity.

Molinist Responses. While Molinists have offered a number of responses to the grounding objection, of particular interest here is the fact that some proponents of middle knowledge have argued that the grounding objection contains some hidden assumptions that necessarily lead to a rejection of Molinism. [It is argued that counterfactuals of creaturely freedom cannot be grounded in God (either his nature or his will) because determinism would follow and/or this would undermine Molinism's claim that counterfactuals are true prevolitionally. Similarly, it is argued that counterfactuals of creaturely freedom cannot be grounded in the causal activity of individuals in the actual world for at least four reasons: (1) the truth of counterfactuals is prior to the individual's existence; (2) the existence of the individual is dependent upon God's will; (3) counterfactuals are not always actualized; 4) character and psychological makeup cannot serve to ground free actions of individual creatures (Flint 1998: 123-124). Five distinct yet related responses to the grounding objection have been set forth by the defenders of the doctrine of middle knowledge. First, several Molinists have denied that the grounding objection is a valid criticism of Molinism because counterfactuals do not need to be grounded. Second, some Molinists have argued that the grounding objection asks the wrong questions because of some hidden assumptions that undermine the Molinist endeavor from the start. Third, some have argued that propositions which refer to free actions in the actual future are no better grounded than counterfactuals of freedom, yet their truth is not questioned. Fourth, some contemporary Molinists have argued that counterfactuals can be grounded in the other-worldly occurrence of the events to which they refer (in the closest-but-not-actual world). Last, some have argued that counterfactuals can be grounded in the persons to whom they refer, as they exist as ideas in the mind of God. It is the second response that is more relevant here.]

For example, Craig notes that it is wrong to ask what causes counterfactuals to be true because this question 'mistakenly assimilates the semantic relation between a true proposition and the corresponding actual state of 
affairs to the causal relation' (Craig 1991: 261). Zagzebski (1991: 143) agrees, noting that the relation between antecedent and consequent in a true counterfactual is weaker than the relation between a proposition and its logical or causal consequence, which is the relation required in Adams's formulation of the grounding objection. The point here is that a causal connection does not have to exist between a proposition and the state of affairs to which it refers for the proposition to be true. A proposition which refers to a state of affairs is true in virtue of the fact that it accurately describes the way things are. The relation between the proposition and the state of affairs is descriptive, not causal. The same principle applies to the truth of counterfactuals. Counterfactuals are true simply because they accurately describe how things would have been. Thus, Craig writes, 'a counterfactual is true in virtue of the fact that its corresponding counterfactual state of affairs obtains. There is thus a reason why the counterfactual is true; its truth has a ground or is founded, if you will; and that reason or ground is its correspondence with reality. But it is misguided to ask who causes it to be true' (Craig 1991: 261). To require a causal explanation for why the counterfactual regarding one's free choices is true beyond appeal to the choice of the individual named or the exercise of the individual's free will is to assume either incompatibilism (i.e., simpliciter) or libertarianism false (Craig 1991: 262).

Similarly, Richard Gaskin (1998: 190) has argued that the grounding objection assumes fatalism. Consider the well-known story of David, King Saul, and the men of Keilah. According to the principle of bivalence (or conditional excluded middle, take your pick), either

If David were to remain in Keilah, Saul would (freely) besiege the city

or

If David were to remain in Keilah, Saul would not (freely) besiege the city

is true. Adams questioned this assertion, proposing that

If David were to remain in Keilah, Saul might or might not besiege the city

can serve as a counterexample to the principle, thus denying the truth of both counterfactuals of freedom. But Gaskin correctly notes that this approach incorrectly construes 'would' in subjunctive conditionals as 'could not but' or 'would have to', and thereby assumes fatalism. The truth that Saul might (or might not) besiege the city does nothing to undermine the truth of the counterfactuals; put differently, the true counterfactual (that Saul would attack) can concurrently be true with the statement that Saul 
might not attack, at least if he is free. To deny this begs the question of FFincompatibilism (Gaskin 1993: 421).

Some determinist opponents of Molinism have begged the question of FF-incompatibilism in their rejection of God's knowledge of counterfactuals of creaturely freedom due to the supposed incoherence of libertarian freedom. Consider Bruce Ware's defense of what he calls Calvinist middle knowledge. [I (Laing 2004; Laing 2013) have elsewhere argued that Ware's notion is incoherent or fatalistic; either way, it fails.] Ware claims that the advantage of Calvinist middle knowledge is that it gives a basis upon which counterfactuals of (compatibilist, i.e., simpliciter) freedom may be true, while (what he calls) Molinist middle knowledge does not due to its libertarian view of freedom.

Ware suggests that God can know the truth of counterfactuals of compatibilist freedom because he knows the contributing causal factors (specifically, the characters, desires, and dispositions of the individuals), along with all the details of the particular situation noted in the counterfactual. By contrast, he argues that if creatures have libertarian freedom, God cannot know the truth of counterfactuals of freedom because libertarianly free choices have no causes (or libertarian freedom is contra-causal). Ware writes, 'The problem for traditional Molinism, with its commitment to libertarian freedom, is that since there is no necessary connection between knowledge of each state of affairs and knowledge of what the agent would in fact choose in each different setting, God could not know the agent's choice by knowing the circumstances' (Ware 2004: 113). Ware contrasts this supposed weakness with a compatibilist view of freedom, where God knows what the agent would do by knowing the causal chain: 'But what if there were a necessary connection between knowledge of a given state of affairs and knowledge of what the agent would choose in that particular setting? If this were the case, then God could know what the agent would choose by knowing fully the circumstances in which the agent would make his choice' (Ware 2004: 113114).

While there are good reasons for doubting Ware's requirement that God deduce the truth of what persons would do by tracing a chain of causes (ultimately back to his own act of will) and for questioning his characterization of libertarian freedom as contra-causal and arbitrary (as it is not advocated by any proponent of libertarian freedom of which I am aware), the point that I wish to make here is that Ware is guilty of the same move as Hasker; he has presupposed that libertarianly free actions and truths about what free creatures will/would do are incompatible. Commenting on a similar argument by one of Molina's Dominican opponents, Diego Alvarez, Gaskin rightly points out that these arguments are question-begging: 'But if it is not supposed that conditionals about what will happen are automatically strict, 
there is no reason why it should be supposed that conditionals about what would happen in hypothetical circumstances are automatically strict' (Gaskin 1993: 421).

Adams's Arguments and Circularity. It is interesting that Fischer should bring up Adams's arguments against middle knowledge-in particular, his arguments regarding the order of God's knowledge and the truth of counterfactuals of creaturely freedom-because Adams has been accused of begging the question. In brief, Adams's argument may be set forth as eleven propositions (Adams 1991).

(1) According to Molinism, the truth of all true counterfactuals of freedom about us is explanatorily prior to God's decision to create us.

(2) God's decision to create us is explanatorily prior to our existence.

(3) Our existence is explanatorily prior to all of our choices and actions.

(4) The relation of explanatory priority is transitive.

(5) Therefore, it follows from Molinism (by 1-4) that the truth of all true counterfactuals of freedom about us is explanatorily prior to all of our choices and actions.

(6) It also follows from Molinism that if I freely do action A in circumstances C, then there is a true counterfactual of freedom $\mathrm{F}^{*}$, which says that if I were in $\mathrm{C}$, then I would (freely) do A.

(7) Therefore, it follows from Molinism that if I freely do A in C, the truth of $\mathrm{F}^{*}$ is explanatorily prior to my choosing and acting as I do in C.

(8) If I freely do $\mathrm{A}$ in $\mathrm{C}$, no truth that is strictly inconsistent with my refraining from $\mathrm{A}$ in $\mathrm{C}$ is explanatorily prior to my choosing and acting as I do in C.

(9) The truth of $\mathrm{F}^{*}$ (which says that if I were in C, then I would do A) is strictly inconsistent with my refraining from $\mathrm{A}$ in $\mathrm{C}$.

(10) If Molinism is true, then if I freely do A in $\mathrm{C}, \mathrm{F}^{*}$ both is (by 7) and is not (by 8-9) explanatorily prior to my choosing and acting as I do in C.

(11) Therefore (by 10) if Molinism is true, then I do not freely do A in C.

As should be clear, this argument is similar to Hasker's discussed earlier.

Molinist Responses. Molinists have charged Adams with begging the question of FF-incompatibilism here, though it is not so obvious because it is tied to his equivocation on the use of 'explanatory priority'. William Lane Craig argues that 'explanatory priority' functions in a different way in (1) from how it functions in (2) and (3). In (2) and (3), it seems to refer to the relationship between consequent and condition, but not so in (1). In order to illustrate his point, Craig rewords (2) and (3):

(2a) If God has not created us, we should not exist.

(3a) If we were not to exist, we should not make any of our choices and actions. 
A moment's reflection will show that this will not work for (1) because

(1a) According to Molinism, if all true counterfactuals of freedom about us were not true, God would not have decided to create us

is false. It seems abundantly clear that God may have chosen to create me, even if some counterfactuals about me had been different. This is made especially clear when a counterfactual which has no bearing (so far as I can tell) on the history of the world is considered. The counterfactual, If John were offered $\$ 100,000,000$ with no strings attached, he would accept, is most likely true in the actual world. I do not know it is true, but I have a high degree of confidence in its truth. At the same time, I also feel quite certain that a world where I am offered $\$ 100,000,000$ with no strings attached is quite distant; I do not foresee any such offers coming my way. If I am correct in this supposition, then it does not seem likely that the counterfactual describing my response to such an offer played a significant role in God's creation decision. What if I really do not know myself so well and I would not accept the offer of $\$ 100,000,000$, even if no strings were attached? It does not appear that anything significant follows because this difference would not change anything in God's creative decision. It follows that, even if the counterfactuals about the creatures God instantiated were different than they in fact are, God still may have chosen to instantiate them. In fact, it seems that there could have been a great many counterfactuals different and God's choice would have remained the same because they would have no impact on the history of the world he actualized. Craig believes that the error in Adams's argument is a confusion of reasons and causes. He writes, 'Adams's mistake seems to be that he leaps from God's decision in the hierarchy of reasons to God's decision in the hierarchy of causes and by this equivocation tries to make counterfactuals of creaturely freedom explanatorily prior to our free choices' (Craig 1994: 859).

Flint has also charged Adams with equivocation in his use of explanatory priority. The key points in Adams's argument, according to Flint, are (1), (2), (3), (4), and (8). Flint notes that Adams seems to imply that explanatory priority should be understood in terms of causal power. For Adams, it appears that $x$ is explanatorily prior to my choices if and only if $x$ is true and there is no choice or action within my power that would cause it to be the case that $x$ is false (Flint 1998: 164). However, he contends that this understanding of explanatory priority will work for points (1), (2), (3) and (4), but not for (8) because it automatically compromises the doctrine of divine foreknowledge. Thus, a causal analysis of explanatory priority will not work. This is similar to the point made earlier about begging the question.

Next, Flint asks whether explanatory priority can be understood in terms of counterfactual power, and it fares no better. In that case, $x$ is ex- 
planatorily prior to my choices and actions if and only if $x$ is true and there is no choice or action within my power such that, were I to so choose or act, $x$ would be false (Flint 1998: 164). This construal does not work in (4) because the counterfactual relation is not transitive. If it were, then the upshot of Adams's argument would be that no matter what the individual named in a counterfactual does, the counterfactual will remain unchanged. This only follows if Adams presupposes that persons do not have counterfactual power over the past.

Flint (1998: 169-171) then considers several other definitions, but none do what Adams needs. He concludes that it is doubtful any such definition can be given. Of course, our point here is simply to note that both of Adams's errors involve begging the question. First, he has begged the question of the compatibility of truths about future or non-actual actions and those actions being free. Second, he has equivocated in his use of explanatory priority, and each use leads to some question-begging problems. An interpretation of explanatory priority in terms of causal power presupposes that divine foreknowledge is incompatible with human freedom. An interpretation of explanatory priority in terms of counterfactual power either presupposes that counterfactuals are false (which is what Adams hopes to prove), or it presupposes that the agent named in the counterfactual does not have counterfactual power over the truth of the counterfactual (which is also what Adams hopes to prove). Either way, Adams has begged the question of FF-incompatibilism.

\section{Timelessness, Ockhamist, and Augustinian Answers}

Not only have open theists and determinists been accused of begging the question, but so have the two most prominent models for defending FFcompatibilism. Divine timelessness and counterfactual power over the past (specifically, God's past beliefs) both seem to include question-begging moves of their own.

The timelessness answer asserts that there is a truth about what the agent will do and that the agent freely acts in eternity, and it is this free act in eternity that affords God his foreknowledge of the event. [I recognize that modern proponents of the model take great pains to speak of simultaneity between events in time and eternity, but the fact remains that if God's knowledge of an event as it occurs in eternity affords him foreknowledge (that is, knowledge of an event prior to its occurrence in time), then the event's occurring in eternity prior to its occurring in time is unavoidable.] Molina himself was skeptical of the timelessness answer to the dilemma because he conceived of it as claiming that events occur in eternity prior to their occurrence in time, and he thought that would destroy their contingency; they would be determined. Proponents of the timelessness view have argued that 
this is not the case and have appealed to some variation of atemporal simultaneity in order to answer this objection, but they have struggled to articulate a sensible explanation of timeless activity and/or atemporal simultaneity. Stump and Kretzmann $(1981,1992)$ have offered ET-simultaneity as an explanation and have charged their critics with begging the question of its incoherence, but they have similarly been charged (Fitzgerald 1985; Nelson 1987; Rogers 1994) with presupposing the coherence of two seemingly contradictory ideas (i.e., begging the question of the coherence of atemporal simultaneity).

Ockhamism has been accused of begging the question of the softness of God's past beliefs and of artificially distinguishing the status of his beliefs from those of other (believing) beings (Zagzebski 1991: 74-75). While I think that these concerns can be answered, it has to be admitted that Ockhamism does appear to presuppose both libertarian freedom and divine foreknowledge. In fact, the key to answering these questions and to Ockhamism working is God's essential omniscience and transcendence. But to be fair, some criticisms of Ockhamism (particularly those that claim it requires power over the past or grants to persons a power they cannot exercise) have missed the point (Adams 1967; Freddoso 1982; Talbott 1986). Perhaps it is best to see the Ockhamist solution as a corollary to the Augustinian position. Just as the Augustinian response denies a causal connection between God's beliefs and future creaturely actions, so the Ockhamist response denies a causal connection between the creatures' actions and God's past beliefs: creatures have the power to act such that God's past beliefs would have always been different from what they, indeed were, but that is not the same thing as the power to cause God's past beliefs to be different from what they actually were.

The point should be clear: if Molinism can be accused of begging the question, it is in good company, for the other positions may also be so accused, and this should not be a cause for concern. It seems to me that underlying this complaint against Molinism is a question-begging rejection of libertarian freedom (or rejection of there being truths about libertarianly free actions prior to their occurrence). If having libertarian freedom built into the structure of counterfactuals is not allowed, then it seems that the viability of the grounding objection has been assumed, and all talk of truth regarding future free actions (of a libertarian sort) must be abandoned.

But what is to be made of Fischer's original accusation, that Molinism assumes an answer to the problem of foreknowledge and free will? In short, he is correct. Molina did build libertarian freedom into the counterfactuals of freedom, and although he saw his system as a separate answer to the dilemma, most contemporary Molinists admit that it makes use of all three of 
the other answers to the dilemma-Augustinian, Ockhamist, and timelessness-in one way or another, though for different reasons/purposes.

Molinism makes use of the Augustinian view when speaking of God's middle knowledge of creaturely actions, but not middle knowledge of his own actions. If God had middle knowledge of his own actions, then he would not be free, but his middle knowledge of creaturely actions does not destroy their freedom. At first glance, this may seem a contradiction, but it is not. God's knowledge of others' actions is not causative and so does not destroy creaturely freedom, but prior knowledge of his own actions would conflict with his own freedom because he is both knower and actor.

Molina rejected the Ockhamist solution, largely because he understood it to rely on God's power to change the past or bring about a past that is different from the past that was actual, notions he saw as incoherent. Yet Molina's own solution to the problem of foreknowledge and free will makes use of the principles underlying the current understanding of Ockhamism. After all, if the opposite really is able to occur (a person really could have acted differently from how s/he did act), as Molina himself admits, then it follows that God's foreknowledge is able to have been different (Craig 1988: 189). This can be seen in Molina's own answer to the charge that middle knowledge leads to fatalism, as God's foreknowledge of $x$ means that $x$ will happen necessarily since there can be no power over the past. Molina maintains that what God now knows cannot be changed, and the future event remains contingent. The future event will obtain as God knows it will obtain, but it could have been otherwise, and if it were otherwise, God would have always known that. Similarly, Molina argues that God's foreknowledge is certain and a foreknown event will certainly occur, but that this does not mean the future event is unable to not occur. In both of these affirmations, then, Molina seems to confirm Fischer's initial point that Molinism depends on another model for reconciling foreknowledge and freedom (i.e., Ockhamism).

Molinism also makes use of the timelessness view of divine eternity as a way of explaining logical priority in the divine decision-making process while avoiding the problems associated with temporal priority. Molinists must hold to this view of divine eternity in order to avoid charges that God's use of counterfactuals of creaturely freedom are part of the world's causal history, thus rendering Molinism deterministic.

While Craig has surely overstated the case when he concludes that 'Molina's reconciliation of divine foreknowledge and future contingency is thus a very novel and provocative one' (Craig 1988: 198), Fischer's suggestion that Molinism adds nothing to the discussion of divine foreknowledge and human freedom because it depends upon the Ockhamist and Augustinian principles is surely incorrect. Molinism adds something to our understand- 
ing of divine foreknowledge by explaining how God knows future contingents contingently while retaining divine freedom. Divine timelessness as an explanation of God's knowledge of the future seems to compromise his own freedom, and Ockhamism offers no insight into how God knows the actual future. Molinism utilizes Augustinian and Ockhamist concepts in a coherent model of providence that allows for both divine foreknowledge and libertarian freedom.

In addition, although all positions may be accused of some questionbegging moves, it does not follow that they are all on an intellectual par such that no adjudication among them is possible, save appeal to one's predilections and preferences. One way to adjudicate among models of providence is to compare how well they handle empirical data. Most scientists agree that randomness exists at the quantum level, even though there is stability, orderliness, and even determinateness at the macro-level. If this is true, then the model which best accords with this reality will have an advantage over the others. Not surprisingly, I will argue that Molinism has the necessary tools to handle randomness and orderliness better than its chief competitors, namely, Calvinism, process theology, and open theism.

\section{Molinism, Randomness, and Determinism/Orderliness}

Calvinism is ill-equipped to deal with genuine randomness, as should be abundantly clear. Ian Barbour rightly takes issue with William Pollard's suggestion that God's providence is located in his control (in a deterministic way) of subatomic and atomic structures/movements. He first objects to the total control afforded God in this model because it leads to predestination, a doctrine Barbour sees as denying human freedom and the reality of evil (Barbour 1990: 117). While Barbour's interpretation of predestination is questionable, he is still correct that Pollard's view is inconsistent with the reality of chance/indeterminacy. Barbour goes on to criticize the model for its lopsided view of providence as divine use of unlawful aspects of nature and for its implicit reductionism, but these are of little concern here. What is important is the removal of real indeterminacy under any deterministic model of providence, no matter how much the proponent wishes to engage modern physical theory.

Proponents of Calvinism typically claim that there is a scientifically indiscernible determining cause of all events, i.e., God's sovereign will, and that the randomness in the universe is only apparent. Claims of randomness at the subatomic level are more a reflection of human ignorance or lack of observational ability than of genuine indeterminacy in nature. As theologian Paul Helm rightly observes, 'Heisenberg's Principle does not have to be understood as a statement about the absence of causal preconditions in the case of those events which it says are uncertain, but to be about the limits of 
our knowledge' (Helm 1994: 143). But he continues, 'And it may be, for all we know to the contrary, that God has freely willed into being a succession of events, some of the latter which are unspecified and unspecifiable in terms of the earlier' (Helm 1994: 144).

How are we to respond to statements such as these? We would be hard pressed to take issue with the basic claim in the latter quote; surely God could bring about events that have no discernible relation to previous events. He could conceivably cause us all to go out of existence at each moment and bring us back into existence at each successive moment. The problem is that we simply have no way of knowing this. In a similar way, we have no way of knowing if God brings about the locations of photons, for example, at each moment in such a way that their locations have no real relation to anything previous. However, this seems to leave the Calvinist with a steadfast faith-claim that is in opposition to observational reality. Put differently, the Calvinist must presuppose that there is either some kind of indiscernible deterministic relationship causing subatomic particle movement, or God is bringing about the locations of subatomic particles at each moment without reference to earlier states. Neither seems particularly attractive.

It is also hard to see how a process view of God can inspire the sort of confidence required in any sort of teleological understanding of reality and theology suggested by orderliness at the macro-level. Although process thinkers have consistently maintained the power of persuasion set against what they see as the only alternative, coercion, it seems unable to ensure the kind of orderliness observed in the natural world. More importantly, it is also impotent to secure the cosmological future that Christian theism proclaims. According to process theology, God preserves each occasion so that in the midst of the coming-into and going-out-of existence of all actual entities, there is something akin to the continuity observed in the world and inferred in theological reflection on the doctrine of divine sustainment, but this preserving work can only maintain whatever process is already at work. It has no mechanism for divine governance of the process and could result in sustenance of processes that work contrary to God's ends. The proponent of process thought must maintain that the eschatological focus of God's selfrealization in becoming either cannot be guaranteed through persuasion alone, or is met no matter what happens because the process itself just is God's self-realization and there is no proper eschatological goal. The former results in an anemic God. As Basinger writes, 'The process theist certainly can hope things will improve. But I see no basis within the system for justifiably coming to believe (having faith) such improvement is probable... Furthermore... there is no basis in process thought for assuming that such a ‘triumph〉 would be 〈ultimate`' (Basinger 1988: 73). The latter results in a 
relativistic universalism (broadly construed) where being and becoming are equated, all states of being/becoming are equally ultimate, and randomness/chance and determinacy/orderliness meld into one and thus are illusory. But this seems to impose a metaphysic far more obscure than anything of which traditional theism has been accused, and conflicts with normal notions of observation, assessment, and coherence!

Open theism is the only model, save Molinism, that seems capable of allowing for genuine randomness at the micro-level and orderliness at the macro-level. So at first glance, we may think it something of a toss-up between the two, with one's proclivities determining which one adopts. However, it seems to me that open theism, like process theology, runs into serious trouble in ensuring orderliness. That is, the God of open theism may get lucky, as it were, so that the random processes at the micro-level just happen to organize themselves in such a way as to produce orderliness, but this outcome has little to do with open theism itself. More importantly, the God of open theism may not get so lucky, and may find the random subatomic activities leading to chaos. At that point, God has two choices: he can allow chaos to reign and simply work with the new situation as Plan B and hope he can non-causally influence things to turn around, or he can intervene and override the natural processes in order to achieve the outcome(s) he desires. Both options are available under open theist principles, but that they are the only seeming options available to God in this situation illustrates my point.

It seems to me that the only way the God of open theism may ensure orderliness at the macro-level by means of random processes at the microlevel is to violate the most basic principles of the model and, in essence, function like the Calvinist God. This is due to the shared assumption of the proponents of Calvinism and open theism-incompatibilism between future contingents and those events truly being contingent, i.e., the grounding objection.

Elsewhere, I have argued that Molinism may prove fruitful in explaining how God could create by means of a process like neo-Darwinism that incorporates random processes (in this case random genetic mutations) by appeal to what I called counterfactuals of random genetic mutation. Truths about how random mutations would in fact result could be used by God to bring about the creatures he desires. At the same time, the limitations Molinism places upon God's ability to determine the true counterfactuals (of freedom and of random genetic mutation) help explain features like vestigial organs which seem problematic for models of creation and intelligent design that use more deterministic assumptions. The argument relies upon analogies between counterfactuals of creaturely freedom and counterfactuals of random genetic mutation and between the free will defense and a similar de- 
fense of intelligent design by progressive creation or evolutionary creation. The most important similarity between the two types of counterfactuals is that they both lack control from without. That is, both libertarianly free actions and random events, by definition, cannot have an external control directing their specific outcomes, but this is not to say that they cannot have true statements about how they will result. [I am loathe to suggest that creaturely freedom is random, thus adding weight to arguments of determinists who claim that libertarian freedom is incoherent and/or arbitrary. Nevertheless, there are some similarities between libertarianly free actions and random events that allow for an analogy.] Just as Molinism allows God to use counterfactuals of creaturely freedom to (weakly) actualize his desires by means of the free actions of his creatures, so also it allows him to establish order and determinateness at the macro-level while retaining genuine indeterminateness at the micro-level by means of counterfactuals of subatomic particle movement. That is, propositions such as

If situation $S$ were to obtain, particle $P$ would randomly move to location $L$

could be used by God to guide and/or govern subatomic particles without causally determining their movements by weakly actualizing situations like $S$ so that the larger picture of the creation is characterized by orderliness. Of course, a few caveats must be noted. First, it could be the case that none of the true counterfactuals of random subatomic particle movement result in the particle being where God wants it (and so God's options are limited by the true counterfactuals). Second, it could also be the case that some minor differences in location of subatomic particles have an effective impact of nil at the macro-level so that the limitations on options have no appreciable effect on God's ability to accomplish his purposes through this random process. Third, there may be no explanation available for what makes counterfactuals of this sort true in that we may not be able to account for the reason why, for example, $P$ moves to $L$ in $S$ rather than (say) $L 2$. Note that all of the caveats presented are no different from the caveats that must be made regarding counterfactuals of creaturely freedom; no special pleading is required. Some may object that there simply could be no true counterfactuals of random subatomic particle movement because they would not thereby be random or because we cannot identify what makes them true, but as should be clear, such objections are simply versions of the grounding objection and are subject to the same criticisms and answers already given by Molinists. Most importantly, they beg the question of the incompatibility of counterfactuals/subjunctive conditionals being true while the processes they describe are random. Still, there are other objections that may demand more comment than reference to the still-unresolved issues of grounding. 
First, some may question the feasibility of the process. There may be many ways for situation $S$ to come about so that, on the one hand, there could potentially be many ways for God to weakly actualize $S$ and get particle $P$ to location $L$ by means of random movement, but on the other hand, the virtually infinite layers of complexity involved here may appear to make such weak actualization virtually impossible, for to arrive at $S$, God would have to weakly actualize another set of random subatomic particle movements, such that an infinite regress results. It seems to me that this potential complaint just raises the issue of the complexity of the creative work of God in a universe characterized by some processes that are random, and while its comprehension poses problems for us, its execution poses not problems for an infinite being. The possibilities regarding particle movement are virtually infinite, but they are not actually infinite, given the finitude of the creation (though even if they were, it would not, in principle, pose a problem for God anyway). If the concept of a truly infinite being is coherent, and most Christians believe that it is no matter their positions on his providence and foreknowledge, then the many layers of complexity and the many factors involved in the governance of random processes do not make divine providence impossible. If anything, they highlight God's majesty.

Second, some may complain that the randomness of the particle movement is removed due to God's 'coercive' activity in actualizing $S$. That is, they may not have a problem with the notion of true counterfactuals of random subatomic particle movement, but may argue that once any effort at regulating their destination(s) is made (even by so-called weak actualization), randomness is by definition removed. Notice that this argument is different in structure from the grounding objection in that it allows for truths regarding results from random processes, and it does not require an accounting of how there can be such truths or what makes them true. But is it fundamentally different from the grounding objection? In one sense, it is clearly different, as already noted, but in another sense it is not, for it has some of the same weaknesses and is based on some of the same assumptions. At its base is a question-begging assumption that randomness and orderliness cannot be reconciled. Any move toward establishing orderliness is automatically deemed destructive of the random nature of subatomic particle movement. In addition, this complaint fails to appreciate that in the model, God's activity is not directly affecting the particle movement, such that there is no coercive, governing, or controlling power acting upon the particle determining its ultimate location. An analogous complaint to counterfactuals of creaturely freedom is to accuse Molinism of destroying freedom because God can set up the conditions where the creature freely acts a certain way, but that can hardly be said to destroy freedom short of begging the question of the grounding objection. 
Third, some have complained that the God of Molinism, like the God of open theism, might (as one of my Calvinist friends put it) 'just get lucky' with respect to the true counterfactuals available to him (whether of creaturely freedom, of random genetic mutation, of random subatomic particle movement, etc.), and so charge Molinism with being unable to ensure the success of God's will. In one sense this is accurate, but in another it is not. Open theism (and to a lesser extent, process theology) has/have available to it/them similar appeals to the idea that variances at the micro-level may have virtually no impact at the macro-level. Still (and here is the genesis of one of the complaints against the model), under Molinist principles, once God decides on a possible world and actualizes it, God is no longer subject to such 'luck', whereas neither open theism nor process theology can make that claim at any stage in the history of the cosmos.

\section{Conclusion}

In this article, I have argued that complaints against Molinism for questionbegging moves are not as detrimental to its success as a philosophical theology as some may think. All views are subject to similar charges in one way or another; determinism and open theism may be charged with begging the question of FF-incompatibilism (and thus rejecting libertarian freedom or divine foreknowledge, respectively). If Molinism is guilty of assuming that God possesses foreknowledge and humans are libertarianly free, namely, of begging the question of FF-compatibilism (by incorporating Ockhamism), so be it. Both the notions of divine foreknowledge and libertarian freedom have strong positions in the history of the Christian church. The burden of proof, then, is on the detractors of Molinism to demonstrate that these are either incoherent notions, or false, or incompatible. Most arguments that have attempted to do so have had to rely on question-begging moves of their own, and so failed to be persuasive.

I have also sought to show that Molinism provides a strong interpretive lens through which theists who are favorably disposed toward intelligent design may understand God's providence in creation in such a way that both randomness and orderliness are preserved. The intellectual power of Molinism and its success at reconciling orthodox Christian notions of providence with scientific empiricism makes it more attractive than its competitors, namely, determinism, open theism, and process theology.

\section{Bibliography}

Adams MM (1967) Is the Existence of God a 'Hard' Fact? Philosophical Review 76(4): 492-503. 
Adams RM (1991) An Anti-Molinist Argument. Philosophical Perspectives 5(1): 343-353.

Barbour I (1990) Religion in an Age of Science. San Francisco, CA: HarperCollins.

Basinger D (1988) Divine Power in Process Theism: A Philosophical Critique. Albany, NY: SUNY Press.

Basinger D (1991) Middle Knowledge and Divine Control: Some Clarifications. International Journal for Philosophy of Religion 30(3): 129-139.

Basinger D (1993) Divine Control and Human Freedom: Is Middle Knowledge the Answer? Journal of the Evangelical Theological Society 36(1): 55-64.

Basinger D (1996) The Case for Freewill Theism: A Philosophical Assessment. Downers Grove, IL: InterVarsity.

Craig WL (1988) The Problem of Divine Foreknowledge and Future Contingents from Aristotle to Suarez. Leiden: Brill.

Craig WL (1991) Divine Foreknowledge and Human Freedom. Leiden: Brill.

Craig WL (1994) Robert Adams's New Anti-Molinist Argument. Philosophy and Phenomenological Research 54(4): 857-861.

Fischer JM (2008) Molinism. In Kvanvig J (ed) Oxford Studies in Philosophy of Religion, volume 1. Oxford: Oxford University Press, pp. 18-43.

Fischer JM (2009) More on Molinism. In Timpe K (ed) Metaphysics and God: Essays in Honor of Eleonore Stump. New York, NY: Routledge, pp. 27-40.

Fischer JM (2012) Putting Molinism in its Place. In Perszyk K (ed) Molinism: The Contemporary Debate. Oxford: Oxford University Press, pp. 208-226.

Fitzgerald P (1985) Stump and Kretzmann on Time and Eternity. The Journal of Philosophy 82(5): 260-269.

Flint TP (1998) Divine Providence: The Molinist Account. Ithaca, NY: Cornell University Press.

Freddoso AJ (1982) Accidental Necessity and Power Over the Past. Pacific Philosophical Quarterly 63(1): 54-68.

Gaskin R (1998) Middle Knowledge, Fatalism, and Comparative Similarity of Worlds. Religious Studies 34(2): 189-203.

Gaskin R (1993) Conditionals of Freedom and Middle Knowledge. The Philosophical Quarterly 43(173): 412-430.

Hasker W (1989) God, Time, and Knowledge. Ithaca, NY: Cornell University Press.

Hasker W (1992) Providence and Evil: Three Theories. Religious Studies 28(1): 91-105.

Hasker W (1994) A Philosophical Perspective. In Pinnock C, Rice R, Sanders J, Hasker W, and Basinger D (eds) The Openness of God: A Biblical Challenge to the Traditional Understanding of God. Downers Grove, IL: InterVarsity, pp. 126-154. 
Hasker W (2004) Providence, Evil, and the Openness of God. New York, NY: Routledge.

Helm P (1994) The Providence of God. Downers Grove, IL: InterVarsity.

Laing JD (2004) The Compatibility of Calvinism and Middle Knowledge. Journal of the Evangelical Theological Society 47(3): 455-467.

Laing JD (2013) Middle Knowledge and the Assumption of Libertarian Freedom: A Response to Ware. In: 65th Annual Meeting of the Evangelical Theological Society, Baltimore, MD, 20 November.

Nelson HJ (1987) Time(s), Eternity, and Duration. International Journal for the Philosophy of Religion 22(1-2): 3-19.

Rogers K (1994) Eternity Has No Duration. Religious Studies 30(1): 1-16.

Sanders J (1998) The God Who Risks: A Theology of Providence. Downers Grove, IL: InterVarsity.

Stump E and Kretzmann N (1981) Eternity. The Journal of Philosophy 78(8): 429-458.

Stump E and Kretzmann N (1992) Eternity, Awareness, and Action. Faith and Philosophy 9(4): 463-482.

Talbott TB (1986) On Divine Foreknowledge and Bringing About the Past. Philosophy and Phenomenological Research 46(3): 455-469.

Ware B (2004) God's Greater Glory: The Exalted God of Scripture and the Christian Faith. Wheaton, IL: Crossway.

Zagzebski LT (1991) The Dilemma of Freedom and Foreknowledge. Oxford: Oxford University Press. 